\title{
PERANCANGAN E-CRM PADA PT MULTI SUPERINDO MANUNGGAL
}

\author{
Brata Wibawa Djojo ${ }^{1}$; Karin Tamara ${ }^{2}$ \\ ${ }^{1}$ PT. Lippo General Insurance, Tbk. Gedung Citra Graha Lantai 6, \\ Jl. Jend. Gatot Subroto Kav. 35 - 36 Jakarta 12950 \\ ${ }^{2}$ Jurusan Manajemen, Fakultas Ekonomi dan Bisnis, Universitas Bina Nusantara, \\ Jln. K.H. Syahdan No. 9, Palmerah, Jakarta Barat 11480
}

\begin{abstract}
ABSTRAK
The key to the success of a company does not only lie in the product or service being offered, but in how far the company's efforts in satisfying the needs of its customers. Results of the system analysis, shows that problems faced by the company are caused by still not optimal customer services. The purpose of this study is to analyze the appropriate strategy for the company and design systems to support the implementation of the strategy. The analytical method used in analyzing the industry with Porter's Five Forces model, and formulation of strategies for using the method of analysis of external and internal environment with matrix IFE and EFE, followed by a SWOT matrix, and strategy decisions based on the matrix QSPM. Results from the formulation of strategy are market penetration strategy. E-CRM system is considered to be the most appropriate in implementation of this strategy and overcoming the problems faced by the company. Web-based e-CRM systems, focusing on the development and maintenance of long-term relationships with customers that can provide added value to both. E-CRM system is expected to make transactions easier for customers to order and get customer service, and also for prospective customers to access accurate company information. Design of E-CRM systems are conducted using $7 C$ method.
\end{abstract}

Keywords: design, E-CRM, SWOT matriks, 7C method

\begin{abstract}
ABSTRAK
Kunci keberhasilan suatu perusahaan bukan semata terletak pada produk atau jasa yang ditawarkan, akan tetapi seberapa jauh upaya perusahaan dalam memuaskan kebutuhan pelanggannya. Hasil analisis sistem yang berjalan menunjukkan bahwa masalah yang dihadapi perusahaan adalah pelayanan perusahaan kepada pelanggannya masih belum optimal. Tujuan dari penelitian ini adalah untuk menganalisis strategi yang tepat bagi perusahaan dan merancang sistem yang mendukung pelaksanaan strategi tersebut. Metode analisis yang dipakai dalam menganalisis industri adalah dengan model lima kekuatan Porter dan perumusan strategi menggunakan metode analisis lingkungan eksternal dan internal perusahaan dengan matriks IFE, dan EFE, dilanjutkan dengan matriks SWOT, dan keputusan strategi berdasarkan matriks QSPM. Hasil dari perumusan strategi adalah strategi penetrasi pasar. Sistem E-CRM dinilai paling tepat untuk mengimplementasikan strategi ini, sekaligus mengatasi permasalahan yang dihadapi perusahaan. Sistem E-CRM yang berbasis web berfokus pada pembangunan dan pemeliharaan hubungan jangka panjang dengan pelanggan yang dapat memberikan nilai tambah bagi keduanya. Sistem E-CRM ini diharapkan dapat mempermudah pelanggan untuk melakukan transaksi pemesanan serta mendapat layanan pelanggan, dan juga untuk calon pelanggan untuk mengakses informasi perusahaan yang akurat. Perancangan sistem E-CRM dilakukan menggunakan metode 7C.
\end{abstract}

Kata kunci: perancangan, E-CRM, matriks SWOT, metode 7C 


\section{PENDAHULUAN}

Untuk menjaga loyalitas dan hubungan dengan pelanggan adalah salah satu tantangan berat yang harus dihadapi perusahaan karena semua orang memiliki karakter yang berbeda-beda satu dan yang lainnya, dan perusahaan harus bisa menghadapi para pelanggannya yag berbeda-beda tersebut dengan baik. Dalam melayani dan menjaga hubungan baik dengan konsumen tentu bukanlah perkara mudah bagi perusahaan. Banyaknya konsumen, waktu yang tersedia, karakteristik yang berbeda dengan keinginan yang berbeda pula merupakan hal yang harus dihadapi perusahaan. Namun, dengan adanya kemajuan teknologi dan internet, perusahaan dimungkinkan untuk menjalin hubungan dengan para pelanggannya yang ada di berbagai tempat, bahkan di luar negeri sekalipun dan menjawab setiap pertanyaan dan keperluan konsumen dengan mudah, cepat, terlebih lagi hemat biaya dan tenaga. ECRM atau Electronic Customer Relationship Management memudahkan perusahaan dalam mengatur dan menjalin hubungan baik dengan para pelanggannya dengan cepat, mudah, dan hemat melalui media elektronik atau internet.

Dalam penelitian ini akan dibahas bagaimana penggunaan internet dalam menjalin hubungan baik dengan para pelanggan perusahaan PT Multi Superindo Manunggal serta faktor internal perusahaan, yaitu kekuatan dan kelemahan perusahaan, dan faktor eksternal perusahaan, yaitu peluang dan ancaman yang dihadapi perusahaan. Masalah yang hendak dijawab lewat penelitian ini adalah (1) Bagaimana merumuskan strategi bisnis PT Multi Superindo Manunggal di masa yang akan datang yang berfokus pada kepuasan pelanggan dalam persaingan dengan perusahaan lain?, dan (2) Bagaimana perancangan E-Customer Relationship Management (E-CRM) yang sesuai bagi PT Multi Superindo Manunggal?. Tujuan dari penulisan ini adalah untuk merumuskan strategi bisnis bagi PT Multi Superindo Manunggal dalam melayani dan meningkatkan kepuasan pelanggan dan merancang E-CRM yang berbasis web bagi PT Multi Superindo Manunggal.

Dulu, banyak perusahaan yang telah berhasil dalam bisnisnya sebelum ditemukannya komputer, dan perusahaan tidak perlu mengatur hubungannya dengan para pelanggan mereka. Akan tetapi, pada pertengahan tahun 1990an, persaingan mulai bertambah ketat, dan CRM ikut berperan penting bagi perusahaan dalam menghadapi ketatnya persaingan dan perubahan yang ada. E-CRM menurut Turban (2008:607), merupakan Customer Relationship Management (CRM) yang dilakukan secara elektronik. Menurut Kalakota (2004:148), E-CRM merupakan manajemen pelanggan untuk eBisnis yang harus berhadapan dengan kompleksitas dari manajemen yang menarik bagi pelanggan dan partner bisnis dalam berbagai macam media, yang meliputi media online dan offline, personal contact, dan media komunikasi elektronik lainnya. E-CRM diperlukan untuk menghemat biaya dan meningkatkan efisiensi dalam mengatur data-data pelanggan. Sistem ini juga mengotomatisasi efisiensi dan kinerja perusahaan dalam hal-hal yang berhubungan dengan pelanggan mereka.

Dengan adanya internet, data mengenai konsumen dapat dengan mudah dibuat dan didapat, dikirimkan ke bagian pemasaran, penjualan, dan bagian layanan konsumen untuk dianalisis. Seiring dengan berubahnya keadaan dan persaingan, E-CRM menjadi salah satu persyaratan bagi perusahaan untuk tetap bertahan; tidak hanya sebagai keunggulan kompetitif perusahaan, akan tetapi E-CRM dapat berhubungan dengan metode, alat, desain harga bagi produk/jasa digital dan program loyalitas konsumen. Analisis CRM (Gambar 1) menurut Turban (2008:611) adalah menerapkan teknik analisis bisnis dan bisnis intelijen seperti data mining dan proses analisis online ke dalam aplikasi CRM. Keuntungan dari analisis CRM adalah dapat mengelompokkan konsumen ke dalam segmen-segmen, hubungan yang lebih produktif dengan konsumen dalam hal penjualan produk/jasa serta peningkatan dalam perencanaan periklanan, strategi pemasaran, manajemen ranta pasokan, biaya yang lebih murah, dan harga yang lebih kompetitif.

The Patricia Seabold Group (2006) mengklasifikasikan aplikasi CRM menjadi 3 kategori, yaitu customer-facing applications, customer-touching applications, dan customer-centric intelligence applications. 


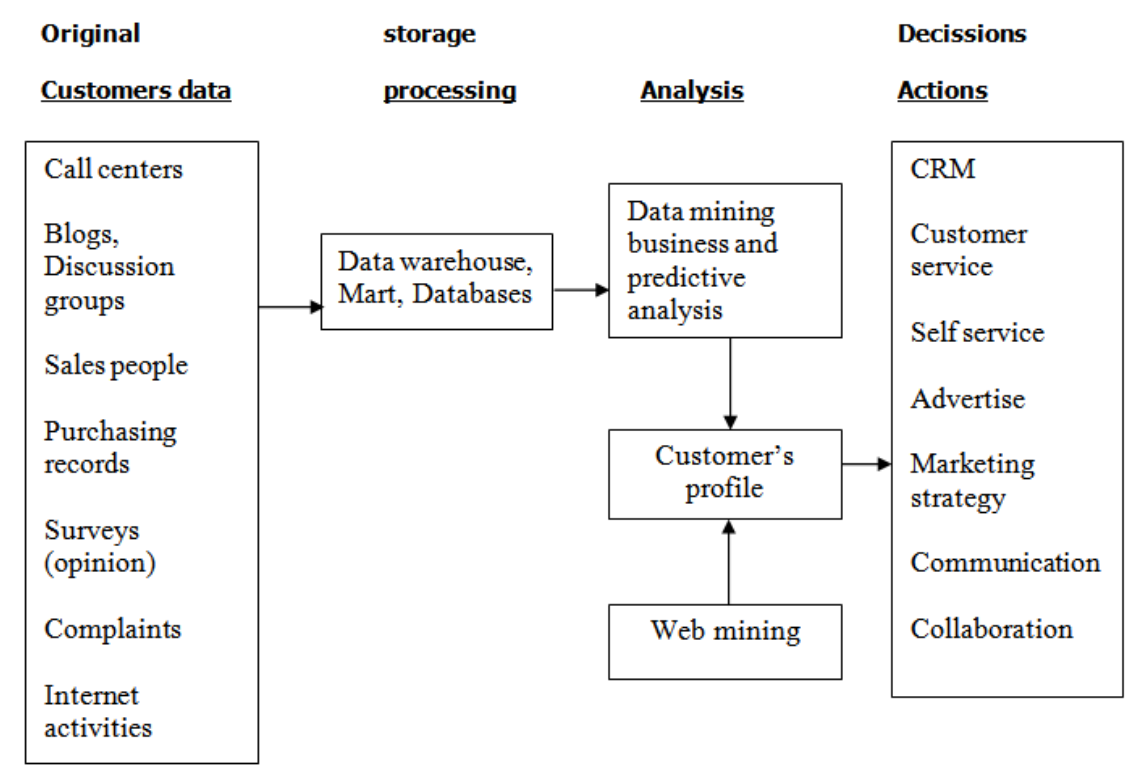

Gambar 1 Analisis CRM

Customer-centric applications merupakan suatu aplikasi yang dapat menganalisis hasil dari proses operasional dan menggunakan hasil yang ada untuk meningkatkan aplikasi CRM yang ada. Aplikasi ini terdiri dari (1) Data reporting and warehousing. Laporan data (data reporting) merupakan data, baik yang mentah maupun yang sudah dianalisis, yang dapat dilihat dan dianalisis oleh manajer. Biasanya data berbentuk tabular atau grafik. Data warehouse adalah suatu media, di mana perusahaan menyimpan data perusahaan dalam suatu server sehingga apabila suatu hari data tersebut dibutuhkan, data itu dapat dengan mudah diakses; (2) Data analysis and mining. Analisis data (data analysis) dapat dilakukan menggunakan aplikasi analisis data yang dapat secara otomatis memproses dan menganalisis data yang ada. Sedangkan data mining adalah suatu proses analisa yang melibatkan data dalam jumlah besar untuk mengetahui pola yang sebelumnya.

Menurut Jagdish N Sheth (2001:47), rantai nilai CRM terdiri dari beberapa tahapan, yaitu Customer Data $\rightarrow$ Customer Information $\rightarrow$ Customer Knowledge $\rightarrow$ Wisdom to Completely Satisfy Customers. Dalam membangun hubungan pelanggan yang baik, perusahaan membutuhkan pengetahuan tentang pelanggan-pelanggannya. Oleh karena itu, suatu perusahaan yang menerapkan CRM membutuhkan manajemen pengetahuan data pelanggan yang baik. Menurut Jagdish N Seth (2001:46), manajemen pengetahuan adalah suatu disiplin manajemen yang menganggap modal intelektual sebagai hal yang bernilai yang harus dijaga dan dikelola dengan baik. Manajemen pengetahuan ini diperlukan untuk memberikan pengertian tentang data dan pengetahuan-pengetahuan yang dapat digunakan untuk mengetahui keinginan pelanggan yang sebenarnya dan memberikan kepuasan lebih bagi pelanggan.

\section{METODE PENELITIAN}

\section{Analisis Kompetitif: Analisis Porter}

Ancaman Pendatang Baru (Threat of New Rivalry) 
Jenis bisnis yang dijalani oleh PT Multi Superindo Manunggal saat ini termasuk dalam salah satu sektor usaha yang potensial. Dalam menjalankan usahanya, PT Multi Superindo Manunggal bermitra dengan 3 perusahaan dan membentuk grup perusahaan, yang terdiri dari PT Multi Sukses Bersama (Jakarta), PT Multi Sejahtera Manunggal (Jakarta), dan CV Multi Manunggal Abadi (Palembang). Adanya perusahaan sejenis yang menggeluti bidang bisnis yang sama dengan PT Multi Superindo Manunggal, membuat PT Superindo Manunggal harus terus meningkatkan keunggulan perusahaan sehingga dapat terus bertumbuh dan dapat bersaing dengan pesaing lainnya.

Pada saat ini, belum ada pesaing baru yang potensial yang menggeluti bidang bisnis seperti PT MSM. Hal ini dikarenakan dibutuhkannya modal yang besar untuk dapat memulai bisnis, hubungan dengan berbagai perusahaan pemasok, baik di dalam maupun luar negeri serta pengetahuan mendalam tentang pipa dan valves, dan faktor keamanan yang harus dipenuhi. Akan tetapi, tetap saja ancaman akan adanya pendatang baru tetap ada, misalnya saja perusahaan yang bermodal besar yang ingin menekuni bisnis ini atau perusahaan luar negeri yang membuka cabangnya di Indonesia.

\section{Pesaing dalam Industri (Competitive Rivalry within an Industry)}

Setiap bisnis yang dijalankan tentunya memiliki pesaing yang mendalami bidang bisnis yang sama dengan perusahaan. Lamanya suatu perusahaan berdiri dan mendalami bidang bisnis, luasnya pangsa pasar yang dikuasai, dan segmen pasar yang sama akan mempengaruhi kuatnya persaingan antar perusahaan yang sejenis. Dalam menghadapi persaingan ini, perusahaan tentunya perlu mempertahankan pelanggan yang sudah ada sekarang, dengan terus meningkatkan kualitas, baik produk maupun pelayanan serta meningkatkan kepercayaan dan loyalitas konsumen, agar terus unggul dibanding pesaing lainnya.

\section{Kekuatan Penawaran Pembeli (Bargaining Power of Customer)}

PT Multi Superindo Manunggal mendalami bidang bisnis penjualan pipa besi, valves, dan lain-lain, dan memiliki konsumen yang sebagian besar adalah perusahaan minyak dan gas serta industri-industri. Dalam menjalankan bisnisnya selama ini, ada kurang lebih 378 perusahaan yang tercatat dalam data PT Multi Superindo Manunggal sebagai pembeli. Adanya beberapa pesaing dalam bisnis sejenis ini membuat kekuatan penawaran pembeli cukup tinggi, dikarenakan pembeli tentunya akan membandingkan harga yang ditawarkan oleh pesaing serta kualitasnya, dengan produk dari PT Multi Superindo Manunggal. Untuk terus mempertahankan pelanggan yang sudah ada sekarang ini, PT Multi Superindo Manunggal terus berusaha untuk memberikan produk dengan kualitas terbaik, aman digunakan, dengan harga kompetitif, dan juga pelayanan terbaik.

\section{Kekuatan Penawaran Pemasok (Bargaining Power of Supplier)}

Dalam menjalankan usahanya, PT Multi Superindo Manunggal tentunya memiliki pemasok yang mendukung dan memberikan suplai barang kepada PT Multi Superindo Manunggal. Sebagai perusahaan yang memiliki taraf internasional, PT Multi Superindo Manunggal pun memiliki banyak pemasok, yaitu kurang lebih 1.102 pemasok, baik di dalam maupun luar negeri. Jumlah tersebut merupakan jumlah yang sangat besar. Banyaknya jumlah pemasok, PT Multi Superindo Manunggal juga merupakan salah satu keunggulan perusahaan, di mana perusahaan tidak hanya bergantung hanya pada satu pemasok saja, melainkan banyak dan mengakibatkan kekuatan penawaran pemasok menjadi lemah.

\section{Ancaman Produk Pengganti (Threat of Substitute Product)}

Sampai saat ini tidak ada produk substitusi yang dapat menggantikan kegunaan pipa besi dan valves. Hal ini disebabkan karena dibutuhkannya pengetahuan dan ukuran yang tepat serta sesuai 
dengan kegunaan pipa yang disesuaikan dengan permintaan pelanggan; dan sampai saat ini, belum ada produk atau barang lain yang dapat menggantikan atau memiliki kegunaan yang sama.

\section{Analisis Strategi Perusahaan}

Perusahaan tumbuh dan berkembang dipengaruhi oleh berbagai faktor. Faktor-faktor yang mempengaruhi perusahaan tersebut antara lain adalah faktor dari luar perusahaan (external factor) dan faktor dari dalam perusahaan (internal factor).

\section{Analisis Faktor Internal dan Eksternal Perusahaan}

Faktor strategi internal perusahaan terdiri dari Kekuatan (strengths), yaitu kualitas produk yang terjamin, teknisi yang handal, standar produk internasional, harga produk yang bersaing, dan banyaknya pemasok perusahaan. Sedangkan kelemahan (weaknesses), yaitu sistem yang belum terintegrasi, website perusahaan yang sederhana, layanan pelanggan yang belum maksimal dalam melayani keinginan pelanggan yang berbeda-beda, prosedur perusahaan yang kompleks, dan biaya yang tinggi dalam pemberian informasi kepada pelanggan.

Sementara itu, faktor strategi eksternal perusahaan terdiri dari peluang (opportunities), yaitu perkembangan industri yang semakin pesat, perkembangan teknologi yang tinggi, banyaknya sumber daya manusia yang ada, pasar yang cukup besar di indonesia, dan adanya koneksi internet yang dapat mempermudah proses bisnis. Sedangkan ancaman (threats), yaitu nilai tukar dollar yang fluktuatif sehingga harga produk tidak stabil, pelanggan yang peka terhadap harga, perusahaan pesaing yang memperbaiki diri dan melakukan perubahan, pemerintah yang membuka peluang bagi perusahaan asing, dan munculnya pesaing baru dalam bisnis.

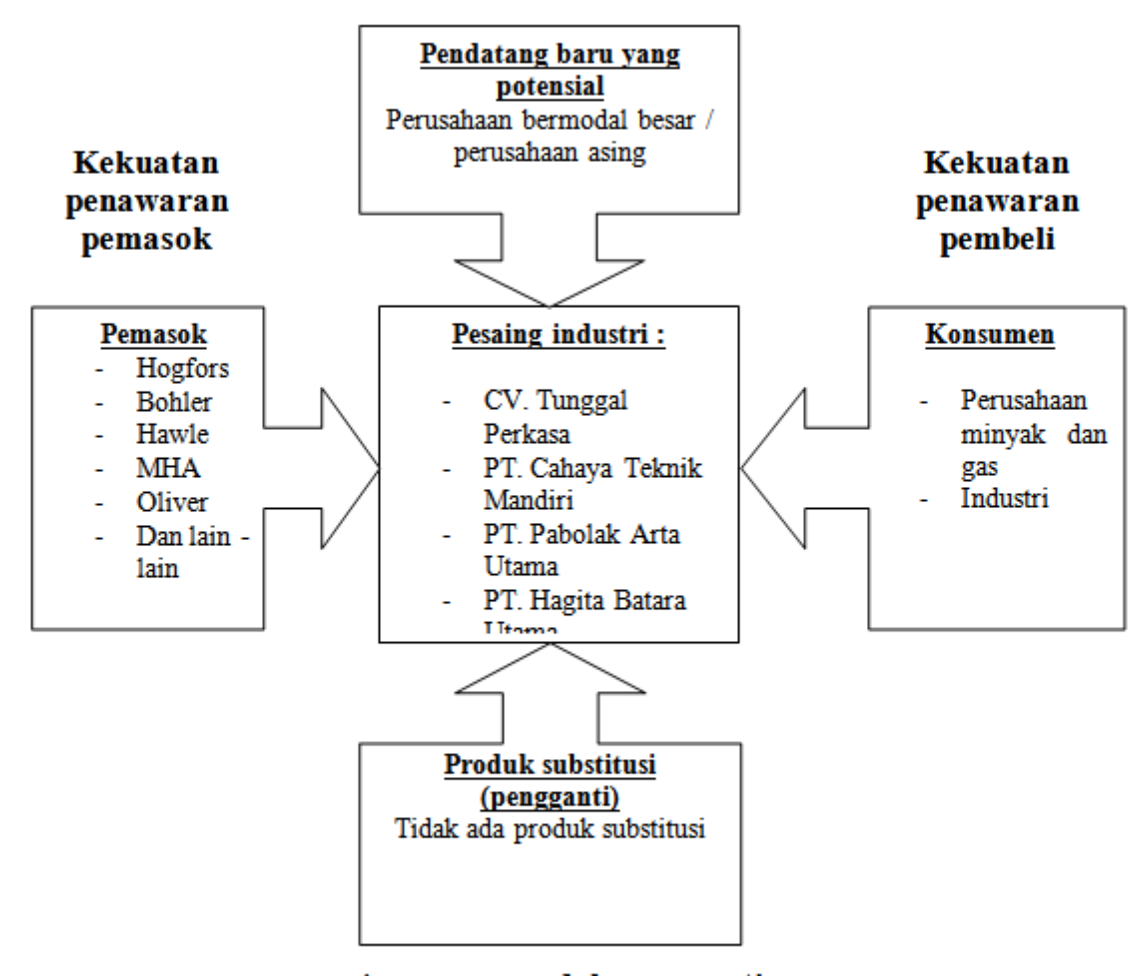

Gambar 2 Diagram Lima Kekuatan Porter PT Multi Superindo Manunggal 


\section{Matriks QSPM (Quantitative Strategic Planning Matrix)}

Matriks QSPM memungkinkan evaluasi alternatif strategi PT Multi Superindo Manunggal secara objektif dan melalui penilaian intuitif yang baik berdasarkan faktor keberhasilan kunci internal dan eksternal yang telah didefinisikan pada tahap sebelumnya.

\section{HASIL DAN PEMBAHASAN}

\section{Penilaian (Assessment)}

Sistem CRM harus dinilai untuk mengetahui seberapa besar sistem yang ada mempengaruhi perusahaan. Tujuan utamanya adalah memberikan konsumen pengalaman positif, dan menanyakan pendapat konsumen tentang pelayanan perusahaan (feedback). Berikut adalah diagram proses pemesanan barang sebelum dan setelah adanya situs E-CRM PT Multi Superindo Manunggal:

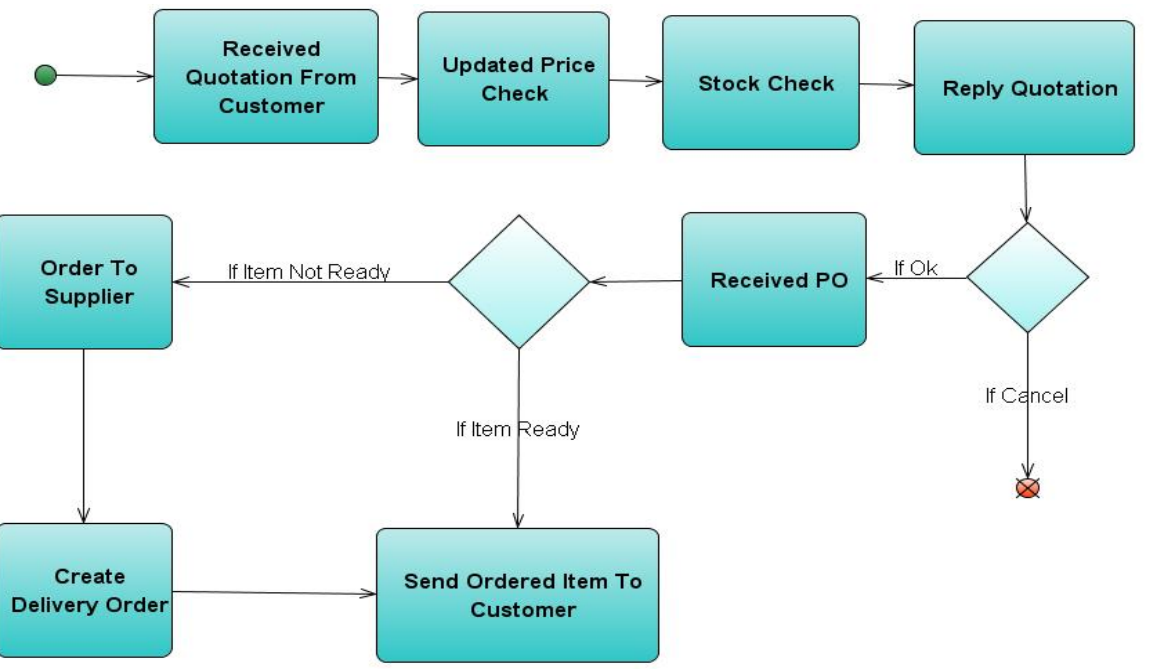

Gambar 3 Diagram Proses Pemesanan Sebelum Perancangan

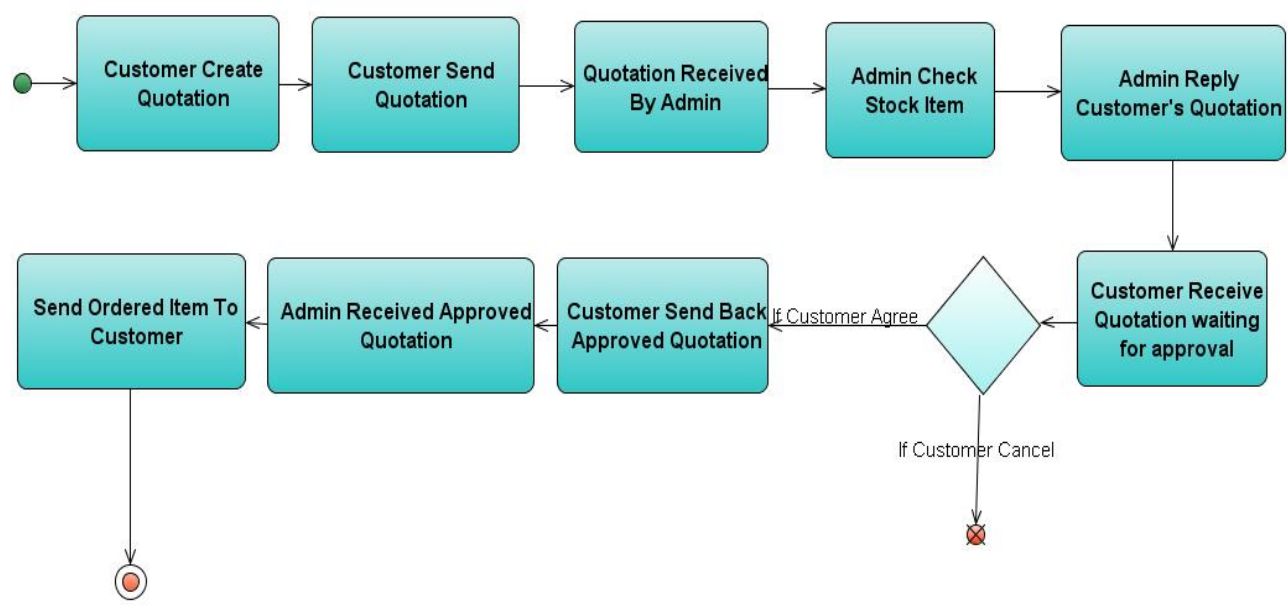

Gambar 4 Diagram Proses Pemesanan dalam Situs PT Multi Superindo Manunggal 
Dari diagram proses pemesanan yang ada pada PT Multi Superindo Manunggal sebelum adanya perancangan situs E-CRM dan sesudah menggunakan situs E-CRM dapat diketahui bahwa dengan menggunakan situs ini, proses pemesanan yang sebelumnya membutuhkan waktu yang lama dan rumit serta menghabiskan biaya dalam penyampaian informasi kepada pelanggan yang biasanya menggunakan media telepon, email, maupun fax, dapat diubah menjadi proses yang lebih singkat serta menghemat waktu dan biaya.

Proses pemesanan barang melalui situs PT Multi Superindo Manunggal lebih mudah serta memberikan informasi yang jelas dan singkat kepada pelanggan mengenai produk yang telah dipesan, harga produk, total pembelian, tanggal pengiriman hingga tanggal barang tersebut sampai di tempat pelanggan. Pelanggan juga dapat melihat kembali pesanan yang telah dilakukannya pada waktu sebelumnya yang tersedia dalam menu pelanggan.

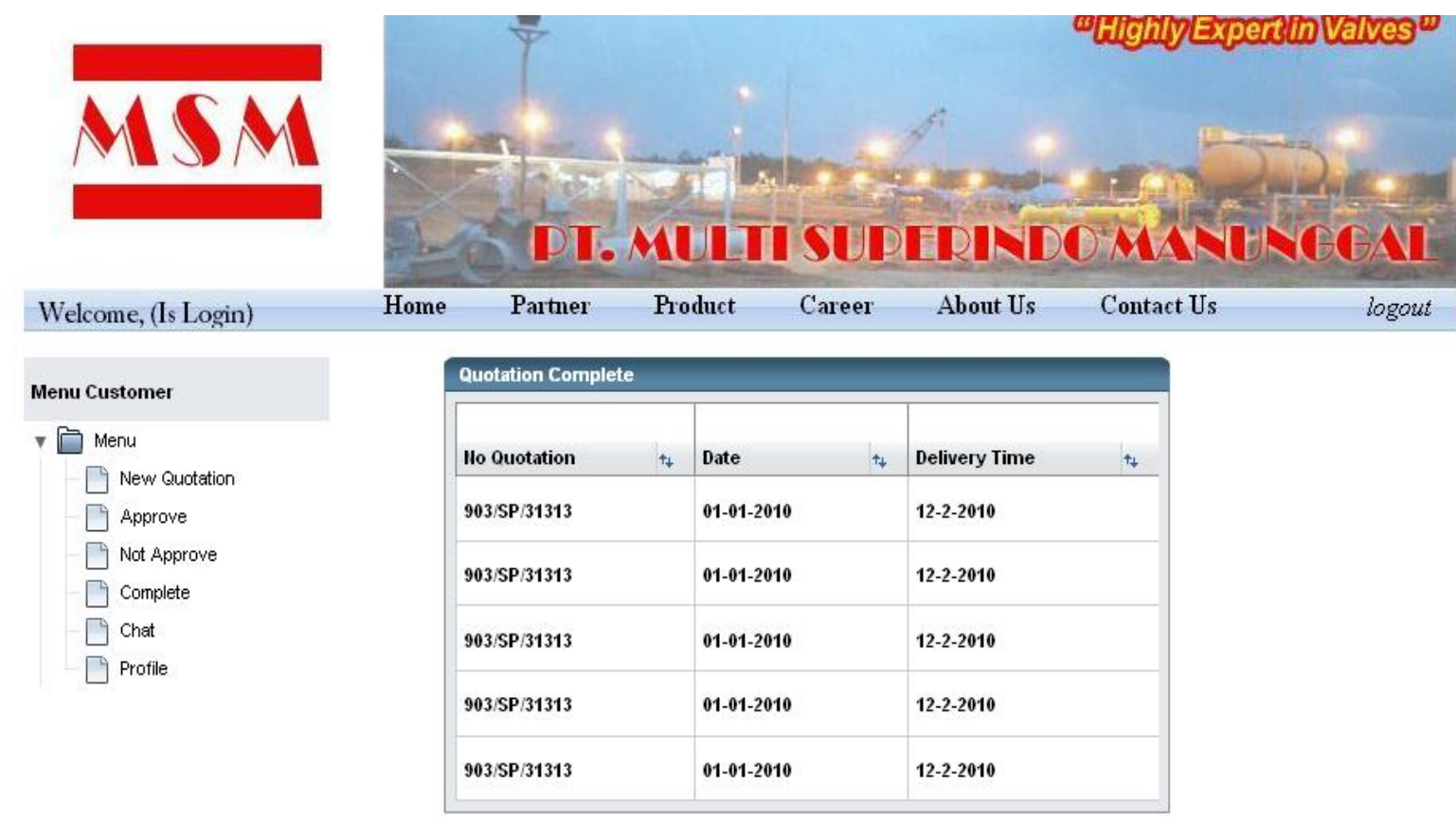

PT MULTI SUPERINDO MANUNGGAL

Gambar 5 Tampilan Halaman History Pesanan Pelanggan

\section{Perbaikan (Correction)}

Perbaikan dilakukan berdasarkan feedback dari konsumen yang dilakukan dalam fase penilaian, dan harus dilakukan untuk meningkatkan/memperbaiki sistem. Situs PT Multi Superindo Manunggal ini menyediakan fitur polling atas seberapa baik atau buruknya kinerja pelayanan dan pemesanan produk dalam situs PT Multi Superindo Manunggal ini. Perusahaan juga menerima masukan saran dari para pengunjung yang mengakses situs PT Multi Superindo Manunggal, yang dapat disampaikan melalui fitur Chat dengan layanan konsumen yang telah tersedia. tersebut terhadap perusahaan dan memberikan pengalaman baik kepada pelanggan; dan tahap terakhir adalah perbaikan di mana perbaikan tersebut dilakukan berdasarkan umpan balik yang diberikan pelanggan untuk meningkatkan kinerja sistem. 


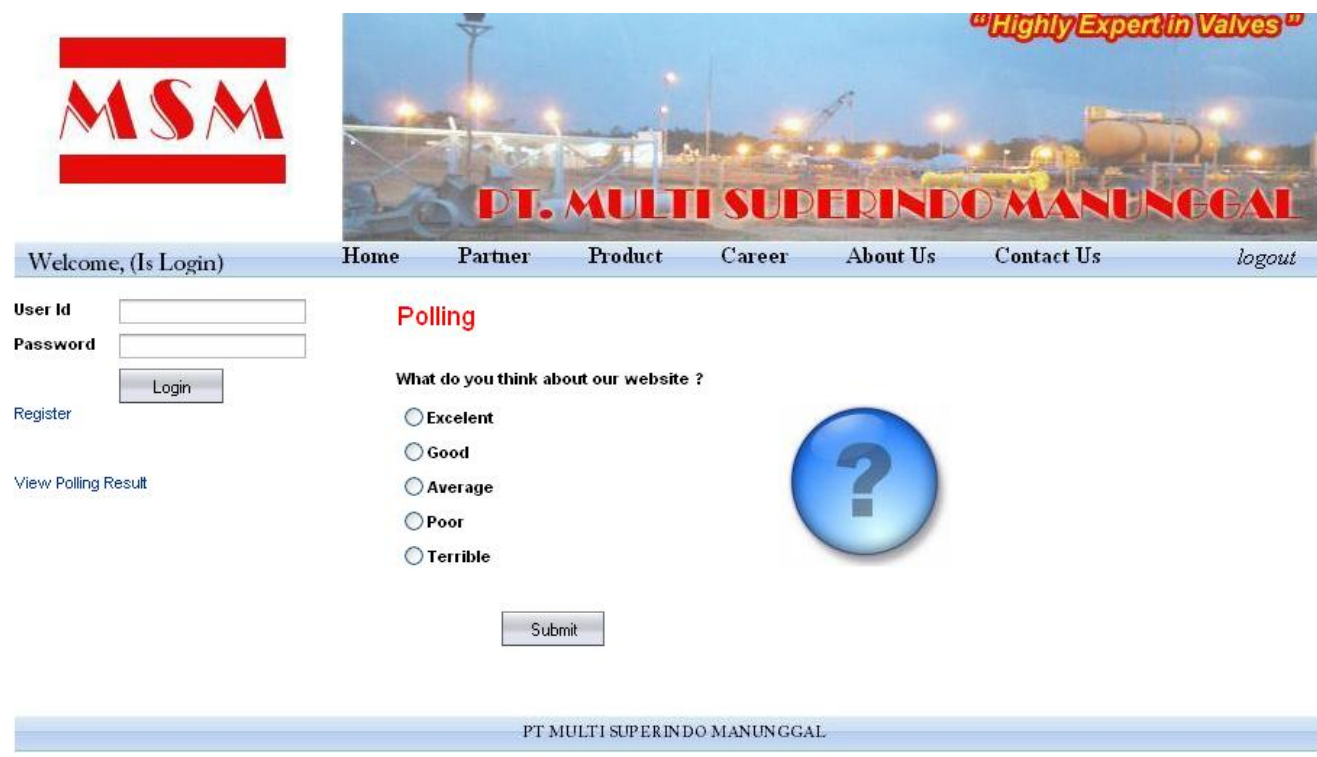

Gambar 6 Halaman Polling Layanan

\section{SIMPULAN}

Sistem E-CRM yang dirancang merupakan sistem berbasis web yang menyediakan fasilitas informasi perusahaan untuk semua pengunjung web, dan halaman khusus pelanggan yang memiliki kepentingan transaksi dengan perusahaan. Saran yang diberikan atas hasil penulisan skripsi ini adalah (1)Melakukan perbaikan layanan kepada pelanggan untuk meningkatkan kepuasan pelanggan, dengan cara meningkatkan pengetahuan tentang produk, kemudahan dalam menyampaikan kritik dan saran, dan meningkatkan fungsi dari pemesanan barang melalui media website yang masih sederhana dan masih perlu dikembangkan; (2) Perlu adanya penambahan informasi mengenai detail produk yang disediakan perusahaan, serta kelengkapan dalam pengisian form pemesanan oleh pelanggan, serta adanya fasilitas customize untuk tampilan layar bagi user. Perlunya diadakan evaluasi secara rutin untuk melakukan perbaikan dan perubahan yang diperlukan untuk menyesuaikan dengan kebutuhan pelanggan; dan (3) Sistem E-CRM ini tidak mendukung mobile. Oleh karena itu, sebaiknya perusahaan mengembangkan agar di masa depan sistem ini dapat mendukung aktivitas mobile.

\section{DAFTAR PUSTAKA}

David, F.R. (2006). Manajemen strategis - konsep, edisi sepuluh, Jakarta: Salemba Empat.

Rangkuti, F. (2009). Analisis SWOT: Teknik membedah kasus bisnis, cetakan keenambelas, Jakarta: PT Gramedia Pustaka Utama.

Sugiyono. (2006). Statistika untuk penelitian, cetakan kesembilan, Bandung: CV Alfabeta.

Umar, H. (2008). Strategic management in action, cetakan kelima, Jakarta: PT Gramedia Pustaka Utama.

Wheelen, T.L., dan Hunger, J.D. (2008). Strategic management and business policy, edisi kesebelas, Upper Saddle River, New Jersey: Pearson Education, Inc. 